\title{
PENGARUH PENDIDIKAN PROTOKOL KESEHATAN PADA SIKAP IBU USIA PRODUKTIF DALAM KEHIDUPAN "NEW NORMAL" UNTUK PENCEGAHAN PENYEBARAN COVID 19
}

\author{
The Effect of Protocol Health Education on attitude productive mother in "new normal" \\ life to prevent spread of covid 19
}

Nevy Norma Renityas ${ }^{1}$

1Program Studi D3 Kebidanan STIKes Patria Husada Blitar

\author{
Alamat Korespondensi : Jl. Sudanco Supriyadi No. 168, \\ Kota Blitar Jawa Timur - Indonesia \\ E-mail: nevy200385@gmail.com
}

\begin{abstract}
ABSTRAK
COVID-19 merupakan penyakit peradangan paru yang disebabkan oleh SARS-CoV-2. Ibu usia produktif tercatat sebagai salah satu kelompok rentan resiko terinfeksi COVID-19 hal ini disebabkan karena terjadinya perubahan fisiologi pada ibu mengakibatkan penurunan kekebalan parsial. Terdapat upaya pencegahan untuk meminimalisir penularan COVID-19 yaitu dengan mematuhi protokol kesehatan, protokol kesehatan ini berupa : mencuci tangan, memakai masker, membatasi mobilisasi, menjaga jarak, menjauhi kerumunan serta pemenuhan nutrisi untuk meningkatkan sistem imun. Tujuan penelitian ini adalah untuk mengetahui pengaruh pendidikan protokol kesehatan covid-19 pada sikap ibu usia produktif dalam kehidupan "new normal" untuk pencegahan penyebaran covid 19 di desa Jatinom Kecamatan Kanigoro Kabupaten Blitar. metode penelitian ini adalah One Group Pretest Postest design. Populasi penelitian ini 15 orang, teknik sampling yang digunakan adalah total sampling. Sampel penelitian ini adalah 15 orang. Instrumen penelitian ini menggunakan kuisioner. Dalam penelitian ini peneliti menggunakan Wilcoxon Seigned Rank Test. Hasil penelitian sebelum diberikan pendidikan protocol kesehatan didapatkan $0 \%$ sikap dengan pengetahuan kategori kurang, $80 \%$ pengetahuan dengan kategori cukup, $20 \%$ sikap dengan kategori baik. Setelah diberikan pendidikan protokol kesehatan didapatkan $0 \%$ sikap dengan kategori kurang, 0\% sikap dengan kategori cukup, 100\% sikap dengan kategori baik. Berdasarkan uji statistic Wilcoxon Signed Rank Test didapatkan $p$ value $=0.001$, sehingga $p$ value $=0.001<\alpha=0.05$ yang berarti menunjukkan adanya pengaruh pendidikan protokol kesehatan tentang pencegahan penyebaran COVID-19 terhadap sikap ibu usia produktif. Diharapkan hasil penelitian ini bisa dijadikan sebagai masukan informasi dan dapat dijadikan sarana pelayanan KIA untuk membantu memberikan upaya pencegahan penularan COVID-19.
\end{abstract}

Kata kunci : Covid-19; ibu usia produktif ; pendidikan protokol kesehatan; sikap

\section{ABSTRACT}

COVID-19 is an inflammatory lung disease caused by SARS-CoV-2. Productive mother listed as one of the vulnerable groups at risk of being infected with COVID-19 this is due to physiological changes in the mother resulting in a decrease in partial immunity. There are prevention efforts to minimize the transmission of COVID-19, namely by complying with health protocols, these health protocols include: washing hands, wearing masks, limiting mobilization, maintaining distance, staying away from crowds and fulfilling nutrition to boost the immune system. The purpose of this study was to determine the effect of covid-19 health protocol education on the attitude of productive mother in a "new normal" life to prevent the spread of covid 19 in Jatinom Village, Kanigoro District, Blitar Regency. This research method is One Group Pretest Posttest design. The population of this study was 15 people, the sampling technique used was total sampling. The sample of this research is 15 people. The research instrument used a questionnaire. In this study, researchers used the Wilcoxon Seigned Rank Test. The results of the study before being given health protocol education obtained 0\% attitudes with knowledge in the poor category, $80 \%$ knowledge in the sufficient category, 20\% attitudes in the good category. After being given 
health protocol education, there were 0\% attitudes in the less category, 0\% attitudes in the sufficient category, 100\% attitudes in the good category. Based on the Wilcoxon Signed Rank Test statistical test, it was found that $p$ value $=0.001$, so $p$ value $=0.001<=0.05$, which means that it shows the effect of health protocol education on preventing the spread of COVID-19 on the attitudes of mothers of productive age. It is hoped that the results of this study can be used as information input and can be used as a MCH service facility to help provide efforts to prevent the transmission of COVID-19.

Keywords: attitude; Covid-19; Protocol Health education; productive mothers

\section{PENDAHULUAN}

Sejak akhir tahun 2019 seluruh bagian dunia dihebohkan dengan Infeksi Novel virus Disease 2019 (COVID-19) atau biasa yang disebut dengan virus Corona. Setelah hampir seluruh negara di belahan dunia terjangkit virus COVID-19 menjadikan situasi ini berkembang menjadi darurat kesehatan masyarakat dunia. COVID-19 merupakan penyakit peradangan paru yang disebabkan oleh Severe Acute Respiratory Syndrome Coronavirus 2 (SARS-Cov-2) (Fauziandari, dkk. 2021).

Ibu usia produktif tercatat sebagai salah satu kelompok rentan resiko terinfeksi COVID-19 hal ini disebabkan karena terjadinya perubahan fisiologi pada ibu usia produktif terutama ibu hamil mengakibatkan penurunan kekebalan parsial(Liang \& Acharya, 2020 dalam Aritonang, dkk., 2020). Sikap merupakan hasil tindakan yang terlihat dari suatu pengetahuan yang dimiliki seseorang. Sikap adalah respon personal individu terhadap perilaku (Rachmat et al., 2013 dalam Budiyati G, dkk. 2021). Sikap juga dapat diartikan sebagai kecenderungan seseorang untuk bertindak, baik mendukung maupun tidak mendukung pada satu objek. Sikap belum merupakan suatu tindakan, tetapi merupakan suatu faktor predisposisi terhadap satu perilaku (Notoatmodjo, 2014). Salah satu upaya untuk meningkatkan sikap ibu usia produktif dalam pencegahan COVID-19 adalah dengan memberikan pendidikan protokol kesehatan.

Pendidikan kesehatan merupakan suatu upaya atau kegiatan yang bertujuan membantu individu, kelompok atau masyarakat untuk meningkatkan kemampuan (perilaku) mereka untuk mencapai kesehatan yang optimal (Alhamda \& Sriani, 2015). protokol kesehatan ini berupa : mencuci tangan, memakai masker, membatasi mobilisasi, menjaga jarak, menjauhi kerumunan serta pemenuhan nutrisi untuk meningkatkan sistem imun. New normal adalah langkah percepatan penanganan COVID-19 dalam bidang kesehatan, sosial, dan ekonomi. Skenario new normal dijalankan dengan mempertimbangkan kesiapan daerah dan hasil riset epidemiologis di wilayah terkait."Badan bahasa sudah memberikan istilah Indonesianya yaitu Kenormalan Baru. Kata Normal sebetulnya dalam bahasa Inggris sudah dijadikan nomina makanya jadi New Normal. Badan bahasa kemudian membuat padanannya menjadi Kenormalan. Karena kalau normal itu 
adjektiva kata sifat, jadi Kenormalan Baru," kata ahli bahasa Prof. Dr. Rahayu Surtiati Hidayat dari Universitas Indonesia. Detiknews, "Tentang New Normal di Indonesia: Arti, Fakta dan Kesiapan Daerah" selengkapnya https://news.detik.com/berita/d -5034719/tentang-new-normal-di-indonesiaarti-fakta-dan-kesiapan-daerah.

Hingga tanggal 3 April 2021 Jawa Timur terdapat kasus terkonfirmasi positif COVID-19 sejumlah 140.331. Total kumulatif kasus COVID-19 di Kabupaten Blitar menempati posisi ke-7 terbanyak di antara 38 Kabupaten dan Kota di Jawa Timur yaitu sebanyak 4.867 kasus terkonfirmasi. Per tanggal 3 April 2021 di wilayah Kecamatan Kanigoro terdapat 19 ibu hamil yang terpapar COVID-19. Desa Jatinom menempati posisi ke 2 di Kecamatan Kanigoro dengan jumlah 15,8\% dari total ibu hamil terkonfirmasi COVID-19. Kecamatan Kanigoro termasuk dalam wilayah fokus dikarenakan jumlah kasus COVID-19 disana cukup tinggi dibandingkan dengan Kecamatan lain di Kabupaten Blitar. Jumlah ibu usia produktif di Jatinom sejumlah 20 orang, jumlah ibu usia produktif ini naik secara signifikan selama peraturan pemerintah untuk membatasi mobilisasi terhadap masyarakat dalam upaya pencegahan penularan COVID-19. Setelah dilakukan wawancara dengan bidan setempat untuk klaster ibu usia produktif COVID-19 di desa Jatinom di dapatkan dari klaster keluarga. Hal tersebut terjadi karena suami atau anggota keluarga yang bekerja diluar kota saat pulang tidak melaksanakan isolasi mandiri atau tidak menerapkan protokol kesehatan. Penuturan menurut bidan bahwa ibu usia produktif saat sudah didalam rumah itu sudah merasa aman dan pasti terhindar dari virus COVID-19. Hal tersebut membuktikan banyak ibu usia produktif yang belum paham dalam penerapan upaya pencegahan penyebaran COVID-19. Tingginya jumlah ibu usia produktif serta adanya beberapa ibu usia produktif yang terpapar COVID-19 diwilayah Jatinom menjadi dasar peneliti mengambil judul "Pengaruh pendidikan protokol kesehatan pada sikap ibu usia produktif dalam kehidupan "new normal" untuk pencegahan penyebaran covid 19 di Desa Jatinom Kecamatan Kanigoro Kabupaten Blitar.

\section{METODE}

Dalam penelitian ini menggunakan rancangan penelitian One Group Pretest Postest design. Dengan cara kelompok subjek diamati sebelum dilakukan intervensi, kemudian diamati lagi setelah intervensi. (Nursalam, 2013) .Populasi adalah wilayah umum yang diterdiri dari objek atau subjek yang mempunyai kuantitas dan karakteristik tertentu yang ditetapkan oleh peneliti untuk mempelajari dan kemudian ditarik kesimpulannya (Hidayat, 2014). Populasi dalam penelitian ini adalah sejumlah $15 \mathrm{ibu}$ usia produktif di Desa Jatinom Kecamatan Kanigoro. Sampel dalam penelitian adalah sejumlah 15 ibu usia produktif di Desa Jatinom Kecamatan Kanigoro.Metode 
pengambilan sampel dalam penelitian ini dengan menggunakan teknik total sampling dimana jumlah sampel sama dengan populasi. metode penelitian ini adalah One Group Pretest Postest design. Instrumen penelitian ini menggunakan kuisioner. Dalam penelitian ini peneliti menggunakan Wilcoxon Seigned Rank Test.Variabel independen dalam penelitian ini adalah pendidikan protokol kesehatan tentang COVID-19. Variabel dependen dalam penelitian ini adalah sikap.

\section{HASIL DAN PEMBAHASAN}

1. Data Khusus

\begin{tabular}{lccr} 
Tabel 1 & Distribusi & frekuensi \\
karakteristik & responden & \multicolumn{2}{c}{ Wilayah } \\
Kerja & Puskesmas & Kanigoro ds \\
Jatinom & Tahun 2021
\end{tabular}

\begin{tabular}{|c|c|c|c|c|}
\hline No & Kriteria & Karakteristik & f & Prosentase \\
\hline \multirow[t]{4}{*}{1} & Pekerjaan & IRT & 8 & $53,3 \%$ \\
\hline & & Tani & 1 & $6,7 \%$ \\
\hline & & Wiraswasta & 6 & $40 \%$ \\
\hline & & PNS & 0 & $0 \%$ \\
\hline \multirow[t]{2}{*}{2} & Usia & $<20$ tahun & 5 & $35 \%$ \\
\hline & & 20-34 tahun & 10 & $65 \%$ \\
\hline \multirow[t]{4}{*}{3} & Pendidikan & SD & 2 & $13,4 \%$ \\
\hline & & SMP & 7 & $46,6 \%$ \\
\hline & & SMA & 6 & $40 \%$ \\
\hline & & PT/AKADEMI & 0 & 0 \\
\hline \multirow[t]{5}{*}{4} & $\begin{array}{l}\text { Sumber } \\
\text { Informasi }\end{array}$ & $\begin{array}{l}\text { Tenaga } \\
\text { Kesehatan }\end{array}$ & 2 & $13,3 \%$ \\
\hline & & Internet & 9 & $60 \%$ \\
\hline & & $\mathrm{TV}$ & 4 & $26,4 \%$ \\
\hline & & Radio & 0 & 0 \\
\hline & & Orang Sekitar & 0 & 0 \\
\hline
\end{tabular}

Dari tabel di atas apat dilihat sebagian besar ibu usia produktif bekerja sebagai IRT, dan usia rata-rata 20-34 tahun (65\%), pendidikan paling banyak SMP sejumlah $(46,6 \%)$, dan sumber informasi kebanyakan dari internet sejumlah $60 \%$.

\section{Data Khusus}

Tabel 2. Hasil pre test sikap ibu usia produktif tentang pencegahan penyebaran COVID-19 sebelum pendidikan protokol kesehatan.

\begin{tabular}{llll}
\hline No & Sikap Ibu & F & Presentase \\
\hline $\mathbf{1}$ & Kurang & 0 & $0 \%$ \\
$\mathbf{2}$ & Cukup & 12 & $80 \%$ \\
$\mathbf{3}$ & Baik & 3 & $20 \%$ \\
\multicolumn{2}{l}{ Jumlah } & 15 & $100 \%$ \\
\hline
\end{tabular}

Berdasarkan tabel 2 menunjukkan bahwa hampir seluruh responden (80\%) sikap ibu usia produktif sebelum diberikan pendidikan protokol kesehatan tentang pencegahan penyebaran COVID-19 dalam kategori cukup.

Sikap responden dengan kategori cukup disini berarti belum tepatnya sikap responden dalam penerapan pencegahan penyebaran COVID-19. Berdasarkan hasil penelitian ini $53.3 \%$ adalah IRT atau tidak bekerja ditunjukkan dengan no responden 2,6,7,8,13,14,15,16 memiliki nilai pretest kurang dari 55 yang berarti sikap mereka kurang terhadap pencegahan penularan COVID-19. Ibu usia produktif yang tidak bekerja cenderung menghabiskan banyak waktunya di rumah dan kurang berinteraksi dengan orang lain karena lebih fokus untuk mengurus rumah tangganya. Hal tersebut dapat menjadi penyebab kurangnya wawasan ibu rumah tangga sehingga dapat mempengaruhi sikap dalam pencegahan penularan COVID-19. Jika dibandingkan dengan ibu usia produktif yang bekerja, peluang wawasan yang didapat kan jauh lebih baik dibandingkan dengan ibu usia 
produktif yang tidak bekerja. Hal ini didukung oleh penelitian yang dilakukan oleh Mindarsih (2018) dengan hasil nilai $p$ value $=$ 0.002 yang berarti terdapat hubungan antara pekerjaan dengan sikap. Pernyataan ini sejalan juga dengan penelitian yang dilakukan oleh Suharmanto (2020) dengan hasil nilai $p$ value $=0.007$ yang berarti terdapat hubungan antara pekerjaan dengan sikap pencegahan penularan COVID-19.

Selain pekerjaan, faktor lain yang menyebabkan sikap ibu usia produktif dalam kategori kurang di penelitian ini adalah usia responden, dimana sebagian besar (53.3\%) usia responden adalah $20-34$ tahun. No responden 1,4,7,11,12,13,15 dengan usia 20 - 35 tahun memiliki nilai pretest kurang dari 58 yang berarti sikap mereka kurang terhadap pencegahan penularan COVID-19. Dengan bertambahnya usia seseorang maka akan terjadi perubahan baik pada aspek fisiologis maupun psikologis. Pada aspek psikologis akan terjadi perubahan kemampuan berfikir seseorang menjadi lebih matang dan dewasa. Selain itu, seiring bertambahnya usia maka semakin banyak pula pengetahuan dan pengalaman yang diperoleh berdasarkan lamanya perjalanan hidup.

Terdapat teori yang menyatakan, bahwa usia 20 - 35 tahun merupakan usia produktif dimana secara aspek psikologis atau mental taraf berfikir seseorang semakin dewasa dan semakin matang dalam pengambilan keputusan untuk merubah sikap dan perilakunya (Mubarak, dkk., 2007 dalam Jawa 2019). Berdasarkan hasil penelitian yang dilakukan Handayani (2020) didapatkan hasil uji statistic $p$ value $=0.001$ yang berarti terdapat pengaruh antara umur ibu terhadap sikap dengan mayoritas ibu hamil berumur 20-35 tahun (95\%). Penelitian ini juga sejalan dengan penelitian yang dilakukan oleh Wulandari dkk (2014) dengan hasil uji statistic $p$ value $=0.031$ yang berarti ada hubungan yang signifikan antara umur responden dengan sikap responden. Sikap responden ini diduga juga dipengaruhi oleh tingkat pendidikan responden yang $46.6 \%$ adalah SMP. Ibu usia produktif yang memiliki pendidikan yang rendah cenderung kurang tepat dalam memahami informasi yang mereka peroleh. Hal tersebut dapat menyebabkan salah pemahaman sehingga mengakibatkan sikap yang dilakukan kurang tepat. Jika dibandingkan dengan ibu usia produktif yang memiliki pendidikan yang lebih tinggi, peluang untuk pemahaman informasi yang mereka peroleh jauh lebih baik. Sehingga mengakibatkan sikap mereka juga tentu lebih baik. No responden 1,3,4,5,7,14,15 dengan pendidikan SD dan SMP memiliki nilai pretest kurang dari 55 yang berarti sikap mereka kurang terhadap pencegahan penularan COVID-19.

$$
\text { Pendidikan dapat menjadikan }
$$
seseorang lebih memahami keadaan dan informasi yang mereka peroleh, sehingga sikap orang yang berpendidikan lebih tinggi akan lebih baik dari pada orang yang dengan berpendidikan rendah. Pemahaman baik dan buruk, salah atau benar, yang menentukan sistem kepercayaan seseorang hingga ikut 
berperan dalam menentukan sikap seseorang (Azwar, 2011). Hasil penelitian ini didukung juga oleh penelitian yangdilakukan oleh Handayani (2020) dengan hasil uji statistik $p$ value $=0.010$ yang berarti bahwa tingkat pendidikan seseorang dapat mempengaruhi sikap. Penelitian ini juga sejalan dengan penelitian yang dilakukan Nurul Aini, dkk (2020) dengan hasil uji statistic $p$ value $=0.03$ yang berarti ada hubungan yang signifikan antara tingkat pengetahuan dengan sikap responden dalam pencegahan COVID-19 di

Desa Kemuningsari Kidul Kabupaten Jember.

Table 3 Hasil post test sikap ibu usia produktif tentang pencegahan penularan COVID-19 sesudah pendidikan protokol kesehatan.

\begin{tabular}{llll}
\hline No & Sikap ibu & F & Presentase \\
\hline $\mathbf{1}$ & Kurang & 0 & $0 \%$ \\
$\mathbf{2}$ & Cukup & 0 & $0 \%$ \\
$\mathbf{3}$ & Baik & 15 & $100 \%$ \\
Jumlah & 15 & $100 \%$ \\
\hline
\end{tabular}

Berdasarkan tabel 2 menunjukkan

bahwa seluruh responden $100 \%$ sikap ibu hamil sesudah diberikan pendidikan kesehatan menggunakan media booklet dengan metode ceramah, peragaan dan tanya jawab tentang pencegahan penularan COVID-19 dalam kategori baik.

Pada penelitian ini perlakuan yang dilakukan peneliti kepada responden dalam upaya perubahan sikap responden kearah yang lebih baik adalah dengan diberikannya pendidikan kesehatan menggunakan media booklet dengan metode ceramah dan peragaan.Faktor-faktor yang mempengaruhi sikap ibu usia produktif baik setelah diberikan pendidikan kesehatan dalam penelitian ini adalah pengetahuan atau informasi tentang COVID-19. Ibu hamil yang belum pernah mendapatkan pengetahuan tentang COVID-19 dapat menjadi penyebab kurangnya sikap tentang pencegahan penularan COVID-19 pada ibu usia produktif. Pengetahuan atau informasi yang didapatkan ibu dapat membantu ibu dalam melakukan sikap tentang pencegahan penularan COVID-19 dengan baik. Sehingga saat setelah diberikan pendidikan kesehatan tentang pencegahan penularan COVID-19 yang disampaikan oleh peneliti akan lebih mudah untuk diserap.

Perubahan sikap dapat terjadi perlahan-lahan seiring dengan bertambahnya informasi dan pengalaman yang didapatkan. Informasi tersebut berasal dari pendidikan kesehatan, pendidikan kesehatan adalah proses transformasi manusia dan terkait erat dengan pencapaian tujuan kesehatan pribadi dan komunitas (Azwar, 2013).

Berdasarkan hasil penelitian yang dilakukan Lubis (2021) perhitungan statistik didapatkan nilai $p$ value $0.005(<0.05)$ yang menunjukkan bahwa secara statistik terdapat hubungan yang signifikan antara tingkat pengetahuan COVID-19 dengan sikap pencegahan terhadap COVID-19. Hal ini sejalan dengan penelitian yang dilakukan Apriani NC, dkk (2017) didapatkan hasil pvalue $=0,000$ yang berarti terdapat hubungan yang bermakna antara pengetahuan dengan sikap. Hasil penelitian dari Wulandari (2020) juga mendukung penelitian ini, 
dimana didapatkan responden yang memiliki pengetahuan baik $(69,2 \%)$ serta memiliki sikap yang baik juga tentang pencegahan COVID-19. Hasil penelitian yang dilakukan oleh Hanovar et al (2020) juga mendukung hasil penelitian ini, dimana mayoritas responden yaitu (67\%) memiliki pengetahuan yang baik selaras dengan sikap pencegahan mereka tentang COVID-19.

Faktor lain yang mempengaruhi sikap ibu usia produktif baik setelah pendidikan kesehatan adalah sumber informasi. Dalam penelitian ini $60 \%$ nya didapatkan sumber informasi dari media internet. Media internet adalah salah satu sumber yang mudah diakses pada zaman sekarang, dimana banyak informasi baru yang mudah disebarluaskan. Hal ini dapat membantu ibu usia produktif mudah dalam mendapatkan informasi yang terbaru terutama dalam pencegahan penularan COVID-19, ibu usia produktif yang sudah mendapatkan atau sering membaca informasi di internet dapat mempengaruhi sikap ibu usia produktif dalam pencegahan penularan COVID-19 kearah yang lebih baik. Menurut Moudy dan Syakurah (2020), salah satu usaha pencegahan pada masyarakat Indonesia adalah dengan mengakses informasi mengenai infeksi COVID 19. Media sosial menjadi sumber berita yang paling banyak diakses oleh hampir $80 \%$ responden tentang Covid-19 seperti WhatsApp, Line, Instagram dan Facebook. Hal ini menyebabkan masyarakat memiliki pengetahuan tentang Covid-19 dan menjadi fenomena yang mendunia karena akses media sosial terjadi setiap detiknya sehingga menyebar dengan mudah dan cepat (Moudy dan Syakurah, 2020).

Berdasarkan hasil penelitian yang dilakukan oleh Solehati T, dkk (2019) didapatkan hasil $p$ value $=0,000$ yang berarti terdapat hubungan yang bermakna antara sumber informasi dengan sikap. Hal ini sejalan juga dengan penelitian yang dilakukan Apriani NC, dkk (2017) didapatkan hasil pvalue $=0,000$ yang berarti terdapat hubungan yang bermakna antara sumber informasi dengan sikap.

Table 4 Pengaruh pendidikan protokol kesehatan terhadap sikap pencegahan penyebaran COVID-19 sebelum dan sesudah diberikan pendidikan protokol kesehatan

\begin{tabular}{llll}
\hline No & Sikap ibu & $\begin{array}{l}\text { Sebelum } \\
\text { pendidikan } \\
(\boldsymbol{\%})\end{array}$ & $\begin{array}{l}\text { Sesudah } \\
\text { pendidikan } \\
(\boldsymbol{\%})\end{array}$ \\
\hline $\mathbf{1}$ & Kurang & 0.0 & 0.0 \\
$\mathbf{2}$ & Cukup & 80 & 0 \\
$\mathbf{3}$ & Baik & 20 & 100 \\
Jumlah & 100 & 100
\end{tabular}

Wilcoxon Sign Rank Test p value : 0.001

Berdasarkan tabel 4 menunjukan bahwa adanya kenaikan presentase sikap ibu usia produktif sebelum dan sesudah perlakuan dengan diberikan pendidikan protokol kesehatan tentang pencegahan penyebaran COVID-19 yaitu sikap dengan kategori baik dari $20 \%$ menjadi $100 \%$.

Berdasarkan uji statistic Wilcoxon Sign Rank Test didapatkan $p$ value $=0.001$, sehingga $p$ value $=0.001<\alpha=0.05$ yang berarti menunjukkan adanya pengaruh 
pendidikan protokol kesehatan terhadap sikap pencegahan penyebaran COVID-19 pada ibu usia produktif di Desa Jatinom Kecamatan Kanigoro.

Adanya perubahan sikap responden tentang pecegahan penularan COVID-19 yang signifikan disebabkan karena diberikannya intervensi pendidikan kesehatan dengan media booklet menggunakan metode ceramah serta peragaan. Dalam penelitian ini menggunakan instrument booklet yang dibagikan pada masing-masing responden, booklet ini berisikan materi tentang pencegahan penularan COVID-19 yang dilengkapi dengan gambar-gambar yang menarik sehingga bisa membuat responden tertarik untuk membacanya. Responden bisa melihat gambar dan uraian materi yang berada di dalam booklet serta dengan mendengarkan penjelasan materi yang diberikan oleh peneliti. Responden terlihat fokus membaca booklet dan terlihat memperhatikan materi serta responden tampak mudah dan senang mengikuti materi yang disampaikan peneliti. Selain booklet, responden juga diberikan peragaan tentang mencuci tangan dengan sabun yang benar dan cara memakai masker yang benar oleh peneliti. Responden tampak semangat dan kooperatif saat diberikan peragaan, peneliti memberikan peragaan pada responden sebanyak 3 - 4 kali kemudian responden langsung bisa melakukan sendiri tanpa dibantu oleh peneliti. Pada penelitian ini terbukti bahwa pendidikan kesehatan berpengaruh terhadap sikap, pendidikan kesehatan yang dilakukan oleh peneliti terlihat mendapatkan respon positif dari responden sehingga responden mampu menerima dan memahami materi yang diberikan oleh peneliti dan pada akhirnya menghasilkan perubahan sikap kearah yang lebih baik pada diri responden. Perubahan sikap pada responden ini didukung oleh pengetahuan responden tentang COVID-19. Dimana pengetahuan responden sebelum pendidikan protokol kesehatan berperan penting dalam proses pemberian materi saat diberikan pendidikan protokol kesehatan. Saat responden sudah memiliki pengetahuan tentang COVID-19 maka lebih mudah untuk peneliti memberikan informasi tentang pencegahan penularan COVID-19. Faktorfaktor yang mempengaruhi sikap responden dilahan salah satunya mendapat informasi atau pengetahuan tentang COVID-19 di internet (media massa) (Azwar, 2013).

Terdapat teori yang dikemukakan Alhamda \& Sriani (2015) pendidikan kesehatan merupakan suatu upaya atau kegiatan yang bertujuan membantu individu, kelompok atau masyarakat untuk meningkatkan kemampuan mereka untuk mencapai kesehatan yang optimal. Peragaan yang digunakan dalam penelitian ini adalah dengan memberikan peragaan tentang cara mencuci tangan menggunakan sabun dengan benar dan cara menggunakan masker dengan benar serta melepas masker dengan benar. Dengan adanya peragaan tersebut ibu usia produktif tidak hanya sekedar tahu tetapi ibu usia produktif dapat memahami dan 
mengikuti serta mempraktikannya. Sehingga pendidikan kesehatan dengan peragaan merupakan salah satu alternatif yang dapat direkomendasikan untuk meningkatkan sikap ibu usia produktif agar terhindar dari infeksi COVID-19. Hal ini didukung oleh pernyataan (Fathurrahman, 2008 dalam Avissa, dkk 2012) bahwa metode dalam pendidikan protokol kesehatan yang diterapkan kepada masyarakat untuk lebih mudah dipahami adalah dengan metode demostrasi atau peragaan. Metode demonstrasi merupakan suatu upaya dengan memperagakan suatu cara agar lebih mudah dalam memahami. Metode Peragaan atau demonstrasi dapat digunakan sebagai bagian dari pembelajaran teori maupun praktik (Gintings, A. 2012). Booklet merupakan media informasi dalam bentuk tulisan dan gambar yang dibuat untuk lebih mempermudah dalam mengarahkan dan memahami informasi karena elemen yang digunakan untuk menyederhanakan suatu data secara praktis dan efektif (Kurniawan, 2004 dalam Avissa, dkk 2012).

Hal ini sejalan dengan penelitian yang dilakukan oleh Ferryanti, dkk (2021) tentang pengaruh penyuluhan pencegahan COVID-19 terhadap pengetahuan dan sikap masyarakat di Kelurahan Wajo Kota Baubau. Berdasarkan hasil analisis pada tabel dengan mengunakan uji $\mathrm{t}$ berpasangan dengan tingkat kemaknaan $\alpha=0.05$ diperoleh $p$ value sebesar 0,000 , dimana $p$ value $<0,05$ yang artinya $\mathrm{HO}$ ditolak dan $\mathrm{Ha}$ diterima hal ini menunjukkan bahwa ada pengaruh penyuluhan terhadap sikap tentang pencegahan COVID-19 di Kelurahan Wajo Kota Bau-ba. Penelitian ini dilakukan dengan metode penyuluhan, sebelum diberikan penyuluhan responden diberikan pre test terlebih dahulu selanjutnya 6 hari kemudian dilakukan post test (Ferryanti dkk, 2021).

Hal ini juga didukung oleh penelitian dari Fauziandari, dkk (2021) tentang sosialisasi pencegahan penularan COVID-19 pada ibu hamil di dusun Ketandan Madurejo Prambanan. Hasil dari penelitian ini adalah terjadinya peningkatan nilai mean pada hasil post test. Nilai mean pre test 9.4 dan nilai mean post test 9.84 berarti dapat disimpulkan bahwa terdapat peningkatan perubahan sikap sebelum dan sesudah dilakukan penyuluhan pada ibu hamil tentang pencegahan penularan COVID-19 .Kegiatan dalam penelitian ini adalah sosialisasi dengan metode ceramah. Penelitian ini dilakukan selama 7 hari untuk mengetahui perubahan sikap (Fauziandari dkk, 2021).

\section{PENUTUP}

Sikap ibu usia produktif dalam pencegahan penularan COVID-19 sebelum diberikan pendidikan kesehatan yaitu $80 \%$ responden dengan sikap kategori cukup. Sikap ibu usia produktif dalam pencegahan penularan COVID-19 setelah diberikan pendidikan kesehatan yaitu $100 \%$ responden dengan sikap kategori baik. Berdasarkan hasil penelitian didapatkan hasil $p$ value $=$ 0.001 sehingga nilai $p$ value $=0.001<a=$ 0.05 yang berarti $\mathrm{H} 1$ diterima yaitu terdapat 
pengaruh pendidikan protokol kesehatan terhadap sikap pencegahan penyebaran COVID-19 pada ibu usia produktif di Desa Jatinom Kecamatan Kanigoro ditunjukkan dari Wilcoxon Signed Rank Test.

\section{UCAPAN TERIMA KASIH}

Atas penyelesaian penelitian ini ucapan terimakasih kepada: 1) Ketua beserta civitas akademika STIKES Patria Husada Blitar, 2) Bidan wilayah beserta staf dan perangkat desa dan kelurahan desa jatinim kecamatan Kanigoro Kabupaten Blitar. 3) Kepala puskesmas dan staf kanigoro yang telah member izin untuk melakukan penelitian di wilayah kerja PKM Kanigoro kabupaten Blitar.

\section{DAFTAR PUSTAKA}

Alhamda, Syukra dan Sriyani, Yustina. 2015. Buku Ajar Ilmu Kesehatan Masyarakat (IKM). Jakarta : Deepublish

Apriani NC, dkk. 2017. Hubungan Pengetahuan dan Sumber Informasi Dengan Sikap Tentang Sekss Pranikah Remaja di SMA 3 Konawe Selatan. Polteknik Kesehatan Kendari

Aritonang, J., Nugraeny, L., Sumiatik, \& Siregar, R. N. (2020). Peningkatan Pemahaman Kesehatan pada Ibu hamil dalam Upaya Pencegahan COVID-19. Jurnal SOLMA, 9(2), 261-269.

https://doi.org/10.22236/solma.v9i2 .5522

Azwar S. 2011. Sikap Manusia : Teori dan Pengukurannya. Yogyakarta : Pustaka Pelajar.

Azwar S. 2013. Sikap Manusia : Teori dan Pengukurannya. Yogyakarta : Pustaka Pelajar.

Budiyati, G., Sari, D., \& Suryati, S. (2021). Pengetahuan, Sikap dan Perilaku
Merokok pada Remaja. Jurnal Ilmiah Permas: Jurnal Ilmiah STIKES Kendal, 11(1),11-18. https://doi.org/https://doi.org/10.32 583/pskm.v11i1.1079

Dashraath P, Wong J, Lim M, Lim L, Li S, Biswas A. et al. Coronavirus disease 2019 (COVID-19) pandemic and pregnancy. Am $\mathrm{J}$ Obstetri Gynecol. 2020;222(6):52131.

https://doi.org/10.1016/j.ajog.2020. 03.021

Estes MI, Mc Allis AK. Maternal immune activation: Implications for neuropsychiatric disorder. Science. 2016;353:772-7.

Fauziandari, E., Wulandari, A., \& Oktamia, R. (2021). Sosialisasi Pencegahan Penularan Covid 19 Pada Ibu Hamil di Dusun Ketandan Madurejo Prambanan. Journal of Community Engagement in Health, 4(1), 45-49. https://doi.org/10.30994/jceh.v4i1.1 $\underline{04}$

Ferryanti, M., dkk. 2021. Pengaruh Penyuluhan Pencegahan COVID19 Terhadap Pengetahuan dan Sikap Masyarakat di Kelurahan Wajo Kota Bau-bau. Jurnal Ilmiah Obsgin P-ISSN : 1979-3340 eISSN : 2685-7987. https://doi.org/10.36089/job.v13i2. 357

Gintings, A. 2012. Esensi Praktis Belajar \& Pembelajaran (Disiapkan untuk Pendidikan Profesi dan Sertifikasi Guru-Dosen). Bandung : Humaniora

Handayani S dan Praise M. 2021. Pengaruh Pendidikan Kesehatan Melali Whatsaap Group Terhadap Pengetahuan dan Sikap Ibu Hamil Dalam Deteksi Dini Preeklamsia Pada Masa Pandemi COVID-19. Jurnal Kebidanan 12 (02) 129-226

Hidayat A. Alimul \& Musrifatul Uliyah. 2014. Pengantar Kebutuhan Dasar Manusia. Edisi 2. Jakarta : Salemba Medika

Honarvar, B. et al. 2020, Knowledge, attitudes, risk perceptions, and practices of adultf toward COVID- 
19 : a population and field-based stdy from Iran, International Journal of Public Health, 65 (6), pp 731-739. DOI : $10.1007 / \mathrm{s} 00038-$ 020-01406-2

Liang, H., \& Acharya, G. (2020). Novel corona virus disease (COVID-19) in pregnancy: What clinical recommendations to follow? Acta Obstetricia et Gynecologica Scandinavica.https://doi.org/10.111 1/aogs.13836

Lubis, DAS. 2021. Hubungan Tingkat Pengetahuan Dengan Sikap dan Perilaku Terhadap pencegahan Infeksi COVID-19 Pada Mahasiswa Semester 6 Fakultas Kedokteran USU. Program Studi Pendidikan Dokter Fakultas Kedokteran Universitas Sumatera Utara Medan.

Mindarsih, Eko. 2018. Karakteristik Suami Yang Berhubungan Dengan Sikap Dalam Menangani Kegawatdaruratan Maternal Dan Neonatal. Jurnal Keperawatan Respati Yogyakarta, [S.1.], v. 5, n. 1, p. 287-294, feb. 2018. ISSN 2541-2728.

doi: http://dx.doi.org/10.35842/jkry .v5i1.164

Moudy J, Syakurah RA. Pengetahuan terkait usaha pencegahan Coronavirus Disease (COVID-19) di Indonesia. Higeia J Public Heal Res Dev. 2020;4(3):333-346.

Notoatmodjo, S. 2014. Ilmu Perilaku Kesehatan. $2^{\text {nd }}$ ed. Jakarta: Rineka Cipta

Nursalam. 2013. Konsep Penerapan Metode Penelitian Ilmu Keperawatan. Jakarta : Salemba Medika

Nurul A, dkk. 2020. Sikap dan Perilaku Pencegahan COVID-19 di Desa Kemuningsari Kidul Kaupaten Jember. https://jurkes.polije.ac.id. Vol.8 No.3 Desember 2020 Hal 171-177. P-ISSN : 2354-5852 | EISSN 2579 5783https://doi.org/10.25047/jkes.v8i3

POGI. Rekomendasi Penanganan Infeksi Virus Corona (COVID-19) pada Maternal (Hamil, Bersalin, dan
Nifas) [Internet]. POGI. 2020 [cited 13 Agustus 2020]. Available from: https ://pogi.or.id/publi sh/wp-content/uploads/ 2020/03/RekomendasiPenanganan-Infeksi-COVID-19padamaternal.pdf.

Phoswa WN, Khaliq OP. Is pregnancy a risk factor of COVID-19? Eur J Obstet Gynecol Reprod Biol. 2020;252:605-9.

Rachmat, M., Thaha, R. M., \& Syafar, M. (2013). Perilaku merokok remaja sekolah menengah pertama. Kesmas: National Public Health Journal, 7(11), 502-508. DOI: http://dx.doi.org/10.21109/kesmas. v7i11.363

Solehati T, dkk. 2019. Hubungan Sumber Informasi Dengan Pengetahuan dan Sikap Siswa SD Dalam Pencegahan Kekerasan Seksual. Volume 5, Nomor 2 Januari 2019. DOI ; $10.33485 /$ jiik-wk/v5i2.124

Wulandari, A. et al. 2020. Hubungan Karakteristik Individu dengan Pengetahuan tentang Penceegahan Coronavirus Diseease 2019 padda Masyarakat di Kalimantan Selatan. Jurnal Kesehatan Masyarakat Indonesia. DOI 10.26714/jkmi.15.1.2020.42-46.

Wulandari, dkk. 2014. Hubungan Karakteristik dan Pengetahuan Perawat dengan Sikap Mendukung Penerapan Program Keselamatan Pasien di RSUD Banjarbaru. Jurnal Publikasi Kesehatan Masyarakat Indonesia (JPKMI) , 1 (1). pp. 13-19. ISSN 2407-1625 